\title{
FIRST RECORDS OF THE GUEST ANT FORMICOXENUS QUEBECENSIS FRANCOEUR FROM WESTERN CANADA (HYMENOPTERA, FORMICIDAE)
}

\author{
By A. Buschinger, R.D. SCHUMANN 1 \\ AND J. HEINZE ${ }^{2}$
}

\begin{abstract}
Formicoxenus quebecensis, a rare guest ant associated with Myrmica alaskensis as yet had been found only in southern Québec. Here we report on five new localities in Alberta and British Columbia. The particular features of $F$. quebecensis, queen and male polymorphism, correspond in both areas.

\section{RESULTS AND Discussion}

Formicoxenus quebecensis Francoeur 1985, a guest ant living in nests of the ant Myrmica alaskensis, as yet has been recorded only from its type locality and vicinity in Québec, Canada, along the north shore of St. Lawrence River between Charlevoix and Havre Saint-Pierre. We here report the discovery of this interesting ant in five sites in Alberta and British Columbia, Canada, demonstrating that it has a much wider range than hitherto known. Despite the large geographical distance between Québec and the new localities, male and queen polymorphism are equally developed both in eastern and western Canada: In F. quebecensis, as in other Formicoxenus species, functional queens may be winged with a fully developed alitrunk ("gynomorphs"), wingless without any wingassociated thoracic structures ("ergatomorphs", though the majority of these specimens are functional workers), or intermediate in morphology, i.e. wingless with wing-related thoracic structures more or less reduced but not absent ("intermorphs"). Similarly, males may be winged or wingless (Francoeur et al. 1985).
\end{abstract}

\footnotetext{
${ }^{1}$ Institut für Zoologie der Technischen Hochschule Darmstadt, Schnittspahnstr. 3, D-64287 Darmstadt, F.R. Germany

2 Theodor-Boveri-Institut (Biozentrum der Universität), LS Verhaltensphysiologie und Soziobiologie, Am Hubland, D-97074 Würzburg, F.R. Germany Manuscript received 28 December 1993.
} 
Colonies of $F$. quebecensis were aspirated from dead wood lying on the ground or from rock crevices. Colonies could not be completely collected because several specimens always quickly escaped into the soil. However, nests of F. quebecensis in Québec were rarely much larger than the colony fragments we collected in western Canada.

Collecting data and sample composition were as follows:

\# 1: 20 August 1979, Alberta, near Obed, south of Yellowhead Highway, in a humid pasture with some shrubs, ca. $900 \mathrm{~m}$ (leg. A.B.). The sample comprised nine ergatomorphs of $F$. quebecensis and one intermorph with three tiny ocelli and a nearly workerlike thorax. No host species was taken, and the sample was listed as "Leptothorax sp.". After the description of $F$. quebecensis (Francoeur et. al. 1985), J. Heinze identified the sample in the collection of A. Buschinger.

\# 2: 27 July 1993, Alberta, Jasper, east of Pyramid Lake, on a rocky hill top in open coniferous forest, ca. $1500 \mathrm{~m}$ (leg. A.B. and R.S.). The nest was found in a dry branch lying on a soilfilled crevice in the rock. The sample comprised 4 alate gynomorphs, 17 intermorphs, 15 ergatomorphs, 12 alate males and 14 wingless, slightly ergatomorphic males. The host colony of Myrmica alaskensis (Wheeler, 1917) inhabited the same branch and the soil beneath it.

\# 3: 28 July 1993, Alberta, Jasper, Marmot Basin Road, ca. 1650m, on a rocky ridge in coniferous forest, in a dry branch (leg. A.B. and R.S.). The sample comprised 2 intermorphs and 5 ergatomorphs of $F$. quebecensis, and a few M. alaskensis workers.

\# 4: 28 July 1993, Alberta, Jasper, Road to Maligne Lake, about $500 \mathrm{~m}$ from the western end of Medicine Lake, ca. 1650m (leg. A.B. and R.S.). The colony was found nesting with $M$. alaskensis in rock crevices in a light pine forest. It comprised 6 intermorphs, 14 ergatomorphs, 16 mainly ergatomorph pupae and two wingless male pupae of $F$. quebecensis. 
\# 5: 20 August 1988, British Columbia, Overlander Falls of Fraser River, ca. $1000 \mathrm{~m}$ (leg. J.H.). The nest was found beneath a rock in the soil in an open coniferous forest. None of the Myrmica hosts were taken. The sample originally contained wingless and winged males. The preserved material comprises one wingless male, 27 workerlike intermorphs, and one ergatomorph; however, an unknown number of specimens were lost during laboratory culture. The number of the remaining specimens therefore is not included in the evaluation below (Tab. $1)$.

The newly collected ants were directly compared with ample material from Québec (collection A.B.), and no morphological differences could be detected. Voucher specimens (two alate and two wingless males, one gynomorph, two intermorphs and three workers, all from colony \# 2 in this paper) have been deposited in the $\mathrm{MCZ}$ at Harvard University. An analysis of several enzymes, which are of diagnostic value in ants related to the Leptothorax (s.str.) complex, namely MDH-1, IDH, PGD and PGI (Heinze 1991), also did not reveal differences between samples from Québec (Waswanipi, Mt. du Lac des Cygnes) and Alberta (Jasper, Pyramid Lake).

The composition of colonies closely matched that reported for collections from Québec (cf. Francoeur et al. 1985).

Gynomorphs are generally rare in Formicoxenus species, ranging in frequency from 1.6 to $4.1 \%$ of all females. Inseminated, fertile intermorphs and ergatomorphs commonly take over queen function, whereas gynomorphic queens have been found in only 3 out of 42 F. quebecensis colonies from Québec (Francoeur et al. 1985). The relative frequencies of the female morphs in our Western Canada collections were very similar to those from Québec colonies (see Table 1).

Table 1: Occurrence of adult female morphs in samples of the guest ant Formicoxenus quebecensis from Québec (data from Francoeur et al. 1985) and Alberta.

\begin{tabular}{|c|c|c|c|c|}
\hline & $\begin{array}{l}\text { Total number } \\
\text { of females }\end{array}$ & $\begin{array}{c}\text { gynomorphs } \\
(\%)\end{array}$ & $\begin{array}{l}\text { intermorphs } \\
(\%)\end{array}$ & $\begin{array}{c}\text { ergatomorphs } \\
(\%)\end{array}$ \\
\hline Québec & 508 & (2.2) & $194 \quad(38.2)$ & $303 \quad(59.6)$ \\
\hline Alberta & 73 & (5.4) & $26 \quad(35.6)$ & $43 \quad(58.9)$ \\
\hline
\end{tabular}


Male dimorphism is a particularly remarkable feature of $F$. quebecensis since it is unique in the genus. Except for $F$. provancheri, which has only black, winged males, Formicoxenus species are characterized by wingless, morphologically worker-like males. $F$. quebecensis represents a perfectly intermediate position, with ordinary winged males (though of paler coloration than in most other ants) and a wingless form with a slightly simplified thorax structure but the long antennae and large compound eyes of normal ant males ("desmaner", according to Loiselle and Francoeur 1988). About 1/2 of the males from Québec were wingless, in the comparatively small sample from Alberta the ratio was 16 wingless to 12 winged males.

Wingless and ergatoid males have been described also for a small number of other ant genera (Loiselle and Francoeur 1988, Heinze and Hölldobler 1993) though little is known as yet on their functions. Of course, wingless males have to mate within, or in close vicinity of their parental colony, and thus often with related females. Male dimorphism, co-occurence of alate and wingless males in one species is much rarer. We speculate that the alate males of $F$. quebecensis fly off for mating and thus counteract inbreeding, while wingless males guarantee the insemination of the resident, mostly also wingless sisters. Another reason for the evolution of wingless males-and queens-in Formicoxenus might be that wing reduction reduces the risk of being captured by the host species workers (Myrmica, Manica, Formica), which occasionally are hostile towards their guests.

Polymorphism of queens, a more frequent feature of other ants, too, might be an adaptation to patchily distributed habitats. Winged queens after mating may fly to distant localities, e.g. with nests of their respective host species, whereas flightless queens remain in the host nest or supercolony. Host nests may house dozens, or in the case of $F$. nitidulus/Formica spp. more than a hundred guest ant colonies. Each host colony thus represents a patch of suitable habitat separated from other such patches by often considerable distances. For a detailed discussion see Buschinger and Heinze (1992) or Heinze and Buschinger (1989).

Two other out of the five North American Formicoxenus species have been recorded from the North West. F. diversipilosus (M.R. Smith, 1939), guest ant of Formica spp., has been intensively studied in the state of Washington by Alpert and Akre (1973), and F. 
provancheri (Emery, 1895) was recorded from Banff, Alberta (Francoeur et al. 1985). The latter coexists with Myrmica incompleta Provancher, apparently throughout at least parts of the range of this species, which extends from New Mexico and Colorado north to Alberta and east to Québec and New England. In the three colonies of $F$. quebecensis from Alberta, in which the host species could be identified, it was Myrmica alaskensis, i.e. the same host ant as in Québec. Our data suggest that $F$. quebecensis is probably also found over a large part of the range of this ant, from Alaska to Labrador (Francoeur 1983).

\section{REFERENCES}

Alpert, G.D., and Akre, R.D. 1973. Distribution, abundance and behavior of the inquiline ant Leptothorax diversipilosus. Ann. Ent. Soc. Am. 66: 753-760.

Buschinger, A., and Heinze, J. 1992. Polymorphism of female reproductives in ants. In: Biology and Evolution of Social Insects (J. Billen, ed.), Leuven Univ. Press, Leuven (Belgium), 11-23.

Francoeur, A. 1983. The ant fauna near the tree-line in northern Québec (Formicidae, Hymenoptera). Nordiana 47: 177-180.

Francoeur, A.; Loiselle, R.; and Buschinger, A. 1985. Biosystématique de la tribu Leptothoracini (Formicidae, Hymenoptera). 1. Le genre Formicoxenus dans la région holarctique. Naturaliste can. (Rev. Ecol. Syst.) 112: 343-403.

Heinze, J. 1991. Biochemical studies on the relationships between socially parasitic ants and their hosts. Biochem. Syst. Ecol. 19: 195-206.

Heinze, J., and Buschinger, A. 1989. Queen polymorphism in Leptothorax sp. A: its genetic and biological background (Hymenoptera: Formicidae). Ins. Soc. 36: $139-155$.

Heinze, J., and Hölldobler, B. 1993. Fighting for a harem of queens: Physiology of reproduction in Cardiocondyla male ants. Proc. Natl. Acad. Sci. USA 90: 8412-8414.

Loiselle, R., and Francoeur, A. 1988. Régression du dimorphisme sexuel dans le genre Formicoxenus et polymorphisme comparé des sexes dans la famille des Formicidae (Hymenoptera). Naturaliste can. (Rev. Ecol. Syst.) 115: 367-378. 

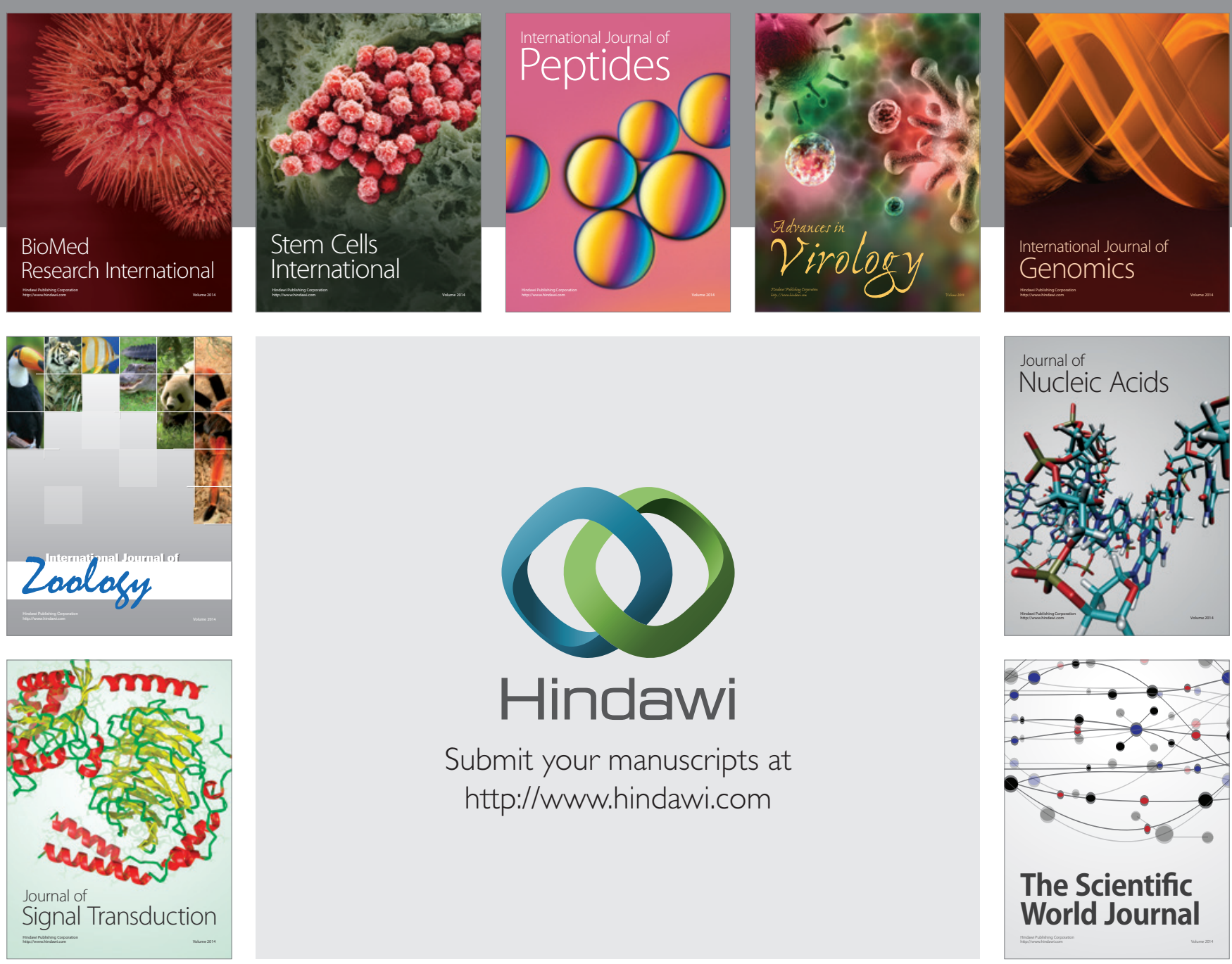

Submit your manuscripts at

http://www.hindawi.com
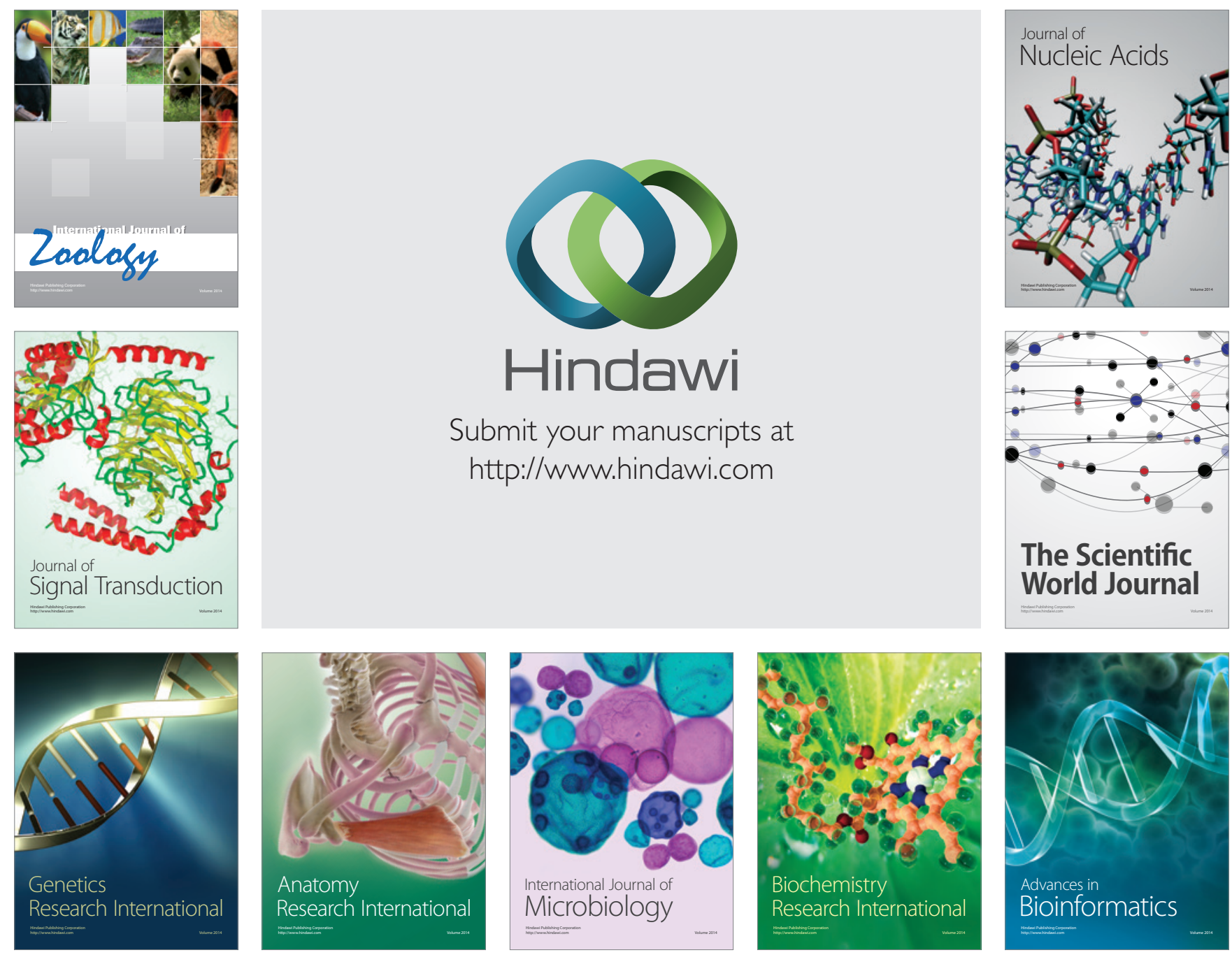

The Scientific World Journal
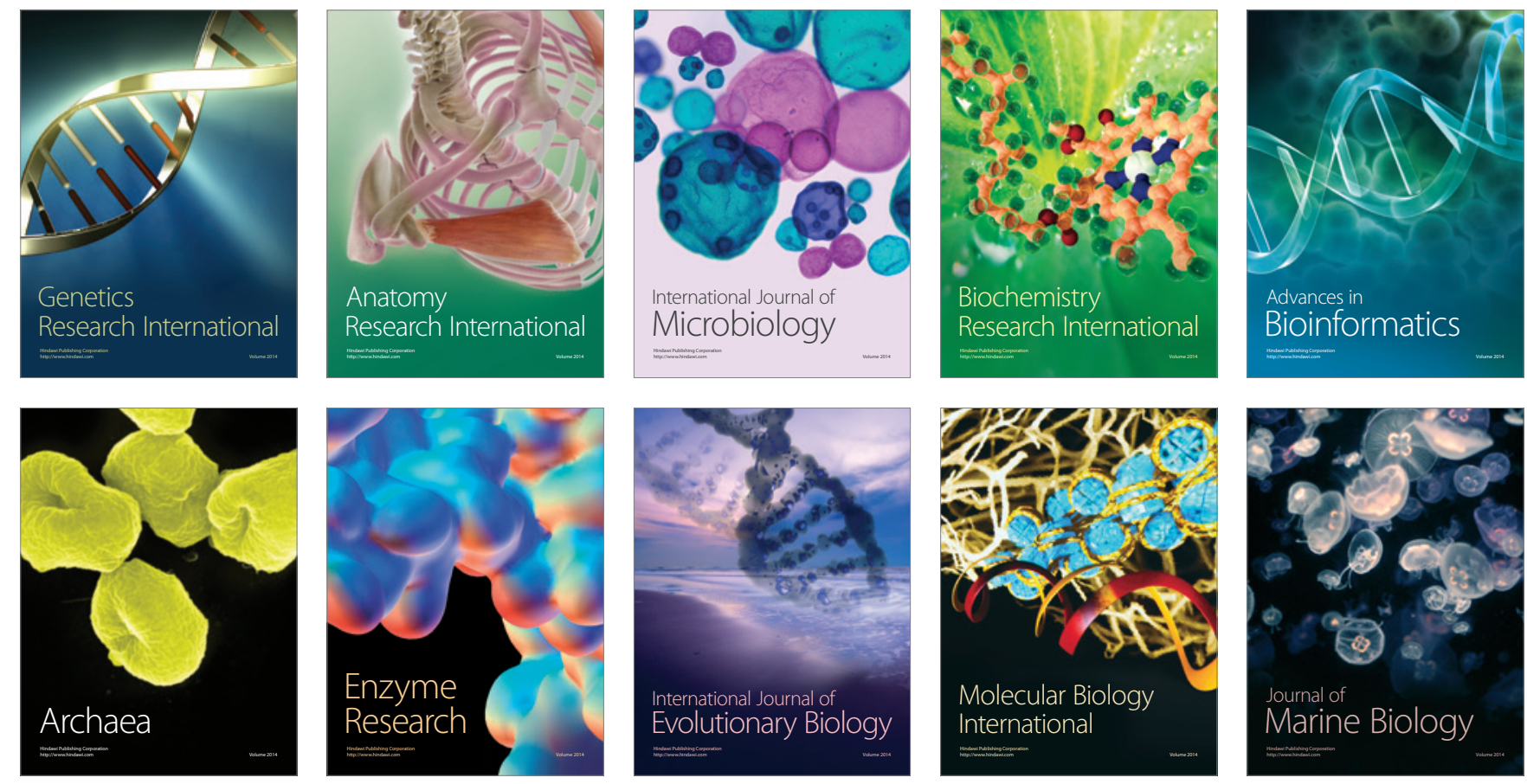